\title{
OBITUARY
}

\section{VISCOUNT RADCLIFFE}

Lord Radcliffe, who died on 1 April 1977, at the age of 78, succeeded Lord Scarbrough as Chairman of the Governing Body of the School of Oriental and African Studies in 1959 and held office for 16 years until in 1975 a period of ill-health led him to resign. During Scarbrough's chairmanship in the decade after the war the outstanding development at the School was the considerable growth in the number of teachers. Under Radcliffe the equally essential and complementary step was taken of reorganizing and largely putting into effect the plans to build an appropriate new home for the School and for the introduction of a substantial body of undergraduate and graduate students in the field of the arts and social sciences. Under these two gifted Chairmen, the shape, size, and broad direction of the School were determined for many years to come.

The School was doubly fortunate in that Radcliffe came to the chairmanship already knowing a great deal about the University of London. For some years during the war he had been Director General of the Ministry of Information with his headquarters in the Senate House and with many of his staff accommodated in the School's own building. As he ruefully admitted, it had fallen to his lot in the exigencies of war to prepare the plan which was put to the Cabinet to take over the whole of the building for the Ministry and to postpone the return of the School to its own home.

In 1958 he had become a member and later Deputy Chairman of the University of London Court, the supreme financial authority in the University, and had gained an understanding not only of the substance of post-war academic affairs but also of the working of the University's somewhat complicated federal system ; and subsequently he never hesitated when discussing the constitutional future to remind the School of the many advantages of that system for a College whose academic work was so highly specialized. Radcliffe had also become interested in the concept of the University's Bloomsbury precinct and was no admirer of the existing buildings. He was glad therefore as one of his early actions as Chairman to encourage the School and the University to entrust the plans for its proposed new building and library to Denys Lasdun, and to put all of his considerable influence at the service of Sir Neville Gass, who as Treasurer of the School was actively raising funds for the proposed development. These decisions were quickly taken, and timely. Had they been delayed even for a couple of years it is likely that the School's ambitions would have been frustrated.

The circumstances surrounding Radcliffe's election as Chairman of the Governing Body are worth dwelling on for they tell us something about the convictions on public service which he held most strongly and about the kind of contribution which he looked to the School to make. His first response to Lord Scarbrough's suggestion that he should succeed as Chairman was to decline on the grounds that outside India he had too little acquaintance with the peoples and countries of Asia and Africa. But a renewed approach, couched in the context of one of his own Reith lectures delivered in 1951 on 'British rule in India' was successful. What moved him and led him to change his mind was the argument that one of the glories of the Indo-British empire was the long line of scholar-administrators which it had fostered and that, with 
the passing of empire, it fell to bodies like the School to remember and perpetuate that fine tradition. Nothing could be more fitting than that he who so admired and in himself embodied that tradition should preside over the School.

It was an idea which caught his imagination and which he dwelt on frequently, not least in the lectures in which he vividly evoked the work, character, and service of Henry Lawrence and Mountstuart Elphinstone in India. Reluctantly accepting that ' these incurious islands do not care greatly for what is done in their name beyond their sight', he did indeed trust that the School would help to keep alive the memory of our countrymen who founded and built up the British administration of India, and especially to call them to mind when 'wondering whether those who are given power must always use it for selfish ends or forget its purpose in the pride of its possession'.

No one who served as a Governor under Radcliffe will forget his brilliance and elegance as a chairman. He believed in short and purposeful meetings. Taking it for granted that every member had read the agenda papers beforehand, and that the sub-committees of the main Body had fully digested their own reports, it was invariably his habit to move with swift certainty through the business. But at the same time so courteous and urbane was his manner, and so masterly his exposition, that all felt that justice was being done and being seen to be done. In his hands the Governors obviously felt secure and happy.

Radcliffe strongly held the view that the academic community should be complete master of its side of the house, and that in academic matters it behoved lay members to tread carefully. At the same time he protected his lay members by declining to accept papers from the Academic Board unless they contained positive, clear-cut proposals on policy. At the slightest hint of any divergence of view between the Governing Body and the Academic Board it was his habit to refer the matter back for further consideration on the academic side.

It was a peculiarly difficult period in the life of the School which was then widely scattered over central London and enduring prolonged discomforts through endless delays in securing a start on its new building. Awkward choices were having to be made on the rate and direction of student expansion and on the extension of work into the social sciences. Controversy occurred frequently and tempers were often raised by wave after wave of militancy. Subjects therefore abounded on which the senior councils might have come to blows, but by authority and skill Radcliffe kept them harmoniously together.

Outside the formal work of the Governing Body, he was punctilious in clearing business promptly, and never failed to respond to approaches from staff or students or union officers. No doubt they were often surprised at the promptness, directness, and pungency of his replies, but none can have failed to get some pleasure from his letters, invariably written in his own distinctive and beautiful handwriting and delightfully precise in both thought and word.

Radcliffe was often despondent and critical about the trends which he discerned in public life and in the universities. He thought that the most noticeable change in the general outlook in Britain since the war had been in a marked lowering of public tone. 'We seem', he said, 'to be losing at an alarming rate the power of independent judgment, the independent sense of value '. He saw egalitarian democracy as in particular nourishing an oppression of the individual personality by its dislike, even fear of privacy, its prim refusal to accept distinctions of value between persons, its obsession with the struggle for material advantages, and he thought that we were becoming 
' a society which combines a low level of thinking and feeling with a wide diffusion of general benevolence and good will '.

Temperamentally therefore he was somewhat less than sympathetic towards claims of staff and students or unions to exercise greater power in the government of the college unless they could show that they were conscious of their responsibilities and qualified to perform them. He was incensed at the growing tendency to deny free speech and at the way in which the life of the School was apt to be disturbed by intolerance and by an unwillingness to accept the true ideals of university education. Although he must often have been sorely tempted to intervene, he regarded the day-to-day running of the School as primarily the Director's responsibility and was therefore scrupulous in holding back until his advice was expressly sought.

Convinced that the physical setting could exert an important influence on public tone, he obviously felt much satisfaction at the transformation brought about in the life of the School by the opening of the new library. He gave encouragement to the Director's policy of creating and displaying throughout the School a collection of paintings, prints, and objects of Oriental and African interest and himself donated generously to it from his own small collection of early prints of India.

Often invited to speak at the School, Radcliffe felt diffident about giving any appearance of coming before a body of specialists as an authority on any aspect of Asia and Africa, even though he had the standing of a Fellow of the British Academy and had been elected an Honorary Fellow of the School itself. Two occasions, however, stand out and remain in the memory. The first was in 1967 at the celebration of the fiftieth anniversary of the School when characteristically without using a note he spoke at length and in detail on the history of the School and on the opportunity that was offered of creating a centre of excellence. The second was at the Director's seminar on the subject of the partition of India when he described his own important personal role in that episode. It was the more memorable because in 1947 he had made up his mind not to write or speak publicly on the subject and he was making an exception. It is worth reminding ourselves of the gist of his account for from it we get some measure of his achievement and character.

With the approval of Indian political leaders Radcliffe had been invited in 1947 by the British government to chair the Boundary Commission which was to draw the frontiers of the proposed new states of India and Pakistan. In London before departing he had been given to understand that some 16 months might be available in which to complete the mission, but on arrival in Delhi the Viceroy told him that the job must be done within six weeks! Since the Bengal and Panjab parts of the Commission were meeting at Calcutta and Lahore respectively and it was plainly impossible for Radcliffe to attend all of their public hearings, he made his own headquarters in Delhi. Unfortunately, neither of the two groups would agree to a common basis for their judgements so that in practice Radcliffe was compelled to make the awards alone.

Through the heat and discomfort of that Delhi summer, with only the briefest of visits to Calcutta and Lahore, working with the available evidence on his desk, Radcliffe systematically drew the two boundaries; and since the requirement was for a continuous line in each province, he did not enjoy the discretion of reserving areas of special difficulty for more leisurely scrutiny.

Radcliffe presented his report within the allotted six weeks and had the satisfaction of seeing it accepted by all the parties concerned. It has stood the test of time and to this day the boundaries thus established have remained 
unchanged. Subsequently, criticism, especially from the side of Pakistan, which was directed against his objectivity and detachment as Chairman of the Commission, greatly hurt him, but it was entirely in character that he should refrain from replying.

His achievement, which had every argument against its success except his own personal quality, was remarkable. He liked to think that in those hot, exhausting weeks in Delhi he had been working in the tradition of Munro and Elphinstone. 'They had', he said, 'fine nerve and they had fine courage; cold courage that kept men doing brave things ... without the expectation of what they did being praised or even recorded. They had pre-eminently a sense of duty.'

It was in that spirit that he personally served the public, and with that judgement on his own work he would be well content.

C. H. PHILIPS 